\title{
Inhibition of breast cancer resistance protein at the murine blood-brain barrier by Ko143 studied with $\left[{ }^{11} \mathrm{C}\right]$ tariquidar and PET
}

\author{
Thomas Wanek ${ }^{1}$, Claudia Kuntner ${ }^{1}$, Jens P Bankstahl ${ }^{2}$, Marion Bankstahl ${ }^{2}$, Johann Stanek ${ }^{1,3}$, Michael Sauberer ${ }^{1}$, \\ Markus Müller ${ }^{3}$, Wolfgang Löscher ${ }^{2}$, Oliver Langer ${ }^{1,3^{*}}$
}

From 17th Scientific Symposium of the Austrian Pharmacological Society (APHAR). Joint meeting with the Hungarian Society of Experimental and Clinical Pharmacology (MFT)

Innsbruck, Austria. 29-30 September 2011

\section{Background}

The ATP-binding cassette $(\mathrm{ABC})$ transporters breast cancer resistance protein (BCRP) and P-glycoprotein (P-gp) are expressed in the blood-brain barrier (BBB), where they impede brain uptake of their substrates by active efflux transport. BCRP has recently been shown to be the quantitatively most important $\mathrm{ABC}$ transporter at the human BBB. Inhibition of BCRP by inhibitors such as the fumitremorgin $C$ derivative Ko143 [1] may be an interesting strategy to improve brain uptake of BCRP substrates. The aim of this study was to assess the dose-response relationship of Ko143 for inhibition of Bcrp1 at the murine BBB using small-animal positron emission tomography (PET) together with the dual $\mathrm{P}$-gp/BCRP substrate radiotracer $\left[{ }^{11} \mathrm{C}\right]$ tariquidar.

\section{Methods}

$\left[{ }^{11} \mathrm{C}\right]$ Tariquidar PET scans were performed in female wild-type (FVB), Bcrp $1^{-1-}$ and $M d r 1 a / b^{-1-}$ mice before and $60 \mathrm{~min}$ after i.v. injection of Ko143 (Axon Medchem BV, The Netherlands) at a dose of $5 \mathrm{mg} / \mathrm{kg}$. Additionally, in $M d r 1 a / b^{-1-}$ mice scans were performed after i.v. administration of vehicle $(\mathrm{n}=2), 1 \mathrm{mg} / \mathrm{kg}(\mathrm{n}=2)$, $3 \mathrm{mg} / \mathrm{kg}(\mathrm{n}=1), 10 \mathrm{mg} / \mathrm{kg}(\mathrm{n}=3)$ and $15 \mathrm{mg} / \mathrm{kg}(\mathrm{n}=$ 2) of Ko143. After the 60-min PET scans a venous blood sample was taken by retro-orbital puncture. Brains were manually outlined on the reconstructed PET images and time-activity curves expressed as

\footnotetext{
* Correspondence: oliver.langer@ait.ac.at

'Health and Environment Department, Molecular Medicine, AIT Austrian Institute of Technology GmbH, 2444 Seibersdorf, Austria Full list of author information is available at the end of the article
}

percent injected dose per gram $(\% \mathrm{ID} / \mathrm{g})$ were generated, for which areas under the curve (AUC) were calculated.

\section{Results}

Wild-type and Bcrp $1^{-1-}$ mice showed no increase in brain AUCs after administration of $5 \mathrm{mg} / \mathrm{kg}$ Ko143 as compared to baseline scans, whereas in $M d r 1 a / b^{-1-}$ mice brain AUC was 4.5 -fold increased. In $M d r 1 a / b^{-1-}$ mice, the half-maximum effect dose of Ko143 to increase brain AUC of $\left[{ }^{11} \mathrm{C}\right]$ tariquidar was $5.6 \pm 2.3 \mathrm{mg} /$ $\mathrm{kg}$. Maximum increase in brain AUC was 8.2-fold after the $15 \mathrm{mg} / \mathrm{kg}$ dose. No changes in blood activity concentrations of $\left[{ }^{11} \mathrm{C}\right]$ tariquidar were found after administration of different Ko143 doses.

\section{Conclusions}

Performing PET scans in $M d r 1 a / b^{(-/)}$mice in combination with the dual P-gp/BCRP substrate $\left[{ }^{11} \mathrm{C}\right]$ tariquidar allowed individual assessment of Bcrp1 inhibition at the BBB. Our data demonstrate that Ko143 is a potent inhibitor of cerebral Bcrp1 in vivo, which apparently does not inhibit P-gp at the studied doses.

\section{Acknowledgements \\ The research leading to these results has received funding from the European Community's Seventh Framework Programme (FP7/2007-2013) under grant agreement number 201380 (Euripides) and from the Austrian Science Fund (FWF) project Transmembrane Transporters in Health and Disease' (SFB F35).}

\section{Author details}

'Health and Environment Department, Molecular Medicine, AlT Austrian Institute of Technology GmbH, 2444 Seibersdorf, Austria. ${ }^{2}$ Department of Pharmacology, Toxicology and Pharmacy, University of Veterinary Medicine, and Center for Systems Neuroscience, 30559 Hannover, Germany. 
${ }^{3}$ Department of Clinical Pharmacology, Medical University of Vienna, 1090 Vienna, Austria.

Published: 5 September 2011

\section{Reference}

1. Allen JD, van Loevezijn A, Lakhai JM, van der Valk M, van Tellingen $\mathrm{O}$, Reid G, Schellens JH, Koomen GJ, Schinkel AH: Potent and specific inhibition of the breast cancer resistance protein multidrug transporter in vitro and in mouse intestine by a novel analogue of fumitremorgin $C$. Mol Cancer Ther 2002, 1:417-425.

doi:10.1186/1471-2210-11-S2-A48

Cite this article as: Wanek et al:. Inhibition of breast cancer resistance protein at the murine blood-brain barrier by Ko143 studied with $\left[{ }^{11} \mathrm{C}\right]$ tariquidar and PET. BMC Pharmacology 2011 11(Suppl 2):A48.

Submit your next manuscript to BioMed Central and take full advantage of:

- Convenient online submission

- Thorough peer review

- No space constraints or color figure charges

- Immediate publication on acceptance

- Inclusion in PubMed, CAS, Scopus and Google Scholar

- Research which is freely available for redistribution

Submit your manuscript at www.biomedcentral.com/submit
Ciomed Central 